\title{
Daeguia caeni gen. nov., sp. nov., isolated from sludge of a textile dye works
}

Correspondence
Jung-Hoon Yoon
jhyoon@kribb.re.kr

\author{
Jung-Hoon Yoon, So-Jung Kang, Sooyeon Park and Tae-Kwang Oh
}

Korea Research Institute of Bioscience and Biotechnology (KRIBB), PO Box 115, Yusong, Taejon, Republic of Korea

\begin{abstract}
A Gram-negative, non-spore-forming, rod-shaped bacterial strain, $\mathrm{K} 107^{\top}$, was isolated from sludge collected from a textile dye works in Korea and its taxonomic position was investigated by means of a polyphasic analysis. Strain $\mathrm{K} 107^{\top}$ contained $\mathrm{Q}-10$ as the predominant ubiquinone. The major fatty acids ( $>10 \%$ of total fatty acids) were $C_{18: 1} \omega 7 c$ and $C_{18: 1} 2-O H$. The DNA $\mathrm{G}+\mathrm{C}$ content was $57.0 \mathrm{~mol} \%$. A phylogenetic analysis based on 16S rRNA gene sequences showed that strain $\mathrm{K} 107^{\top}$ was closely related to the genera Mycoplana, Brucella and Ochrobactrum. Strain $\mathrm{K} 107^{\top}$ exhibited $16 \mathrm{~S}$ rRNA gene sequence similarity values of 96.3$97.1 \%$ with respect to the type strains of two Mycoplana species and 94.8-96.8\% with respect to members of the genera Brucella and Ochrobactrum. A phylogenetic analysis based on recA gene sequences showed that strain $\mathrm{K} 107^{\top}$ forms a distinct phylogenetic lineage within the Alphaproteobacteria. The $\operatorname{rec} A$ gene sequence of strain $\mathrm{K} 107^{\top}$ showed similarity values of $84.5 \%$ with respect to type strains of Brucella species and values of 77.6-83.1\% with respect to members of the genera Pseudochrobactrum, Ochrobactrum and Mycoplana. Strain K107 ${ }^{\top}$ could be differentiated from phylogenetically related genera by differences in phenotypic properties and fatty acid profiles. On the basis of phenotypic, chemotaxonomic and phylogenetic data, strain $\mathrm{K} 107^{\top}$ represents a novel genus and species, for which the name Daeguia caeni gen. nov., sp. nov. is proposed. The type strain of Daeguia caeni is strain $\mathrm{K} 107^{\top}$ (=KCTC $12981^{\top}=\mathrm{CCUG}$ $\left.54520^{\top}\right)$.
\end{abstract}

In the course of the screening of micro-organisms from the wastewater treatment plant of a textile dye works in Korea, many bacterial strains were isolated and characterized taxonomically (Yoon et al., 2007a, b, c, d). This study focuses on one of these isolates, designated strain $\mathrm{K}_{107^{\mathrm{T}}}$. Comparative 16S rRNA gene sequence analysis indicated that strain $\mathrm{K}_{107^{\mathrm{T}}}$ is phylogenetically closely related to the family Brucellaceae within the Alphaproteobacteria. The aim of the present work was to determine the exact taxonomic position of strain $\mathrm{K} 107^{\mathrm{T}}$ by using a polyphasic characterization that included determination of its phenotypic properties and detailed phylogenetic analyses based on its $16 \mathrm{~S}$ rRNA and recA gene sequences.

Strain $\mathrm{K}_{107^{\mathrm{T}}}$ was isolated on trypticase soy agar (TSA; Difco) at $30{ }^{\circ} \mathrm{C}$ using the standard dilution plating

The GenBank/EMBL/DDBJ accession numbers for the 16S rRNA gene sequences of strain $\mathrm{K} 107^{\top}$, Mycoplana dimorpha DSM $7138^{\top}$ and Mycoplana ramosa DSM $7292^{\top}$ are EF532794, EU022307 and EU022308, respectively, and that for the recA gene sequence of strain

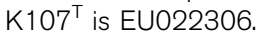

Cellular fatty acid compositions for strain $\mathrm{K} 107^{\top}$ and two Mycoplana type strains are presented in a supplementary table available with the online version of this paper. technique. Mycoplana dimorpha DSM $7138^{\mathrm{T}}$ and Mycoplana ramosa DSM $7292^{\mathrm{T}}$, which were used as reference strains for fatty acid analyses, were obtained from the Deutsche Sammlung von Mikroorganismen und Zellkulturen (Braunschweig, Germany). The morphological, physiological and biochemical characteristics of strain $\mathrm{K}_{107^{\mathrm{T}}}$ were investigated using routine cultivation on TSA at $37{ }^{\circ} \mathrm{C}$. Cell morphology was examined by using light microscopy (E600; Nikon) and transmission electron microscopy with cells from exponentially growing cultures. Flagellation was determined by using a Philips CM-20 transmission electron microscope with cells from exponentially growing cultures: for this purpose, the cells were negatively stained with $1 \%(\mathrm{w} / \mathrm{v})$ phosphotungstic acid and the grids were examined after being air-dried. The Gram reaction was determined using the bioMérieux Gram stain kit according to the manufacturer's instructions. Growth at various temperatures $\left(4-60{ }^{\circ} \mathrm{C}\right)$ was investigated on TSA. The $\mathrm{pH}$ range for growth was determined in nutrient broth (Difco) adjusted to various $\mathrm{pH}$ values ( $\mathrm{pH} 4.5-10.5$, in increments of $0.5 \mathrm{pH}$ units) by the addition of $\mathrm{HCl}$ or $\mathrm{Na}_{2} \mathrm{CO}_{3}$. Growth in the absence of $\mathrm{NaCl}$ and at various $\mathrm{NaCl}$ concentrations $(0.5 \%, \mathrm{w} / \mathrm{v}$, and 1.0 $7.0 \%, \mathrm{w} / \mathrm{v}$, using increments of $1.0 \%$ ) was investigated using trypticase soy broth prepared according to the 
formula of the Difco medium except that $\mathrm{NaCl}$ was excluded. Growth under anaerobic conditions was determined after incubation in an anaerobic chamber on TSA and on TSA supplemented with potassium nitrate $(0.1 \%$, $\mathrm{w} / \mathrm{v})$, both of which had been prepared anaerobically under nitrogen. Catalase and oxidase activities and hydrolysis of casein, gelatin, hypoxanthine, starch, Tweens 20, 40, 60 and 80 , tyrosine, urea and xanthine were determined as described by Cowan \& Steel (1965). The hydrolysis of aesculin and the reduction of nitrate were studied as described previously (Lanyi, 1987). Susceptibility to antibiotics was tested on TSA plates using antibiotic discs containing the following: polymyxin B, $100 \mathrm{U}$; streptomycin, $50 \mu \mathrm{g}$; penicillin $\mathrm{G}, 20 \mathrm{U}$; chloramphenicol, $100 \mu \mathrm{g}$; ampicillin, $10 \mu \mathrm{g}$; cephalothin, $30 \mu \mathrm{g}$; gentamicin, $30 \mu \mathrm{g}$; novobiocin, $5 \mu \mathrm{g}$; tetracycline, $30 \mu \mathrm{g}$; kanamycin, $30 \mu \mathrm{g}$; lincomycin, $15 \mu \mathrm{g}$; oleandomycin, $15 \mu \mathrm{g}$; neomycin, $30 \mu \mathrm{g}$; and carbenicillin, $100 \mu \mathrm{g}$. The utilization of various substrates, enzyme activities and other physiological and biochemical properties were tested by using the API 20E, API 20NE, API $50 \mathrm{CH}$ and API ZYM systems (bioMérieux). The cells were suspended in AUX medium, according to the manufacturer's instructions, for inoculation of the API $50 \mathrm{CH}$ system.

Cell biomass for DNA extraction and for isoprenoid quinone analysis was obtained from cultivation in trypticase soy broth (Difco) at $37^{\circ} \mathrm{C}$. Chromosomal DNA was isolated and purified according to the method described by Yoon et al. (1996), with the exception that RNase T1 was used in combination with RNase A to minimize contamination with RNA. The 16S rRNA gene was amplified by using a PCR with two universal primers, 5'-GAGTTTGATCCTGGCTCAG-3' and 5'-AGAAAGGAGGTGATCCAGCC-3', as described previously (Yoon et al., 1998). PCR amplification of a partial recA gene was performed by using two primers, $5^{\prime}$-CGKCTSGTAGAGGAYAAATCGGTGGA-3' and $5^{\prime}$-CGRATCTGGTTGATGAAGATCACCAT-3', as described by Gaunt et al. (2001). Sequencing of the amplified 16S rRNA and recA genes and phylogenetic analysis were performed as described by Yoon et al. (2003). Isoprenoid quinones were extracted according to the method of Komagata \& Suzuki (1987) and analysed using reversed-phase HPLC and a YMC ODS-A $(250 \times 4.6 \mathrm{~mm})$ column. For the cellular fatty acid analysis, cell mass of strain $\mathrm{K} 107^{\mathrm{T}}$, M. dimorpha DSM $7138^{\mathrm{T}}$ and M. ramosa DSM $7292^{\mathrm{T}}$ was harvested from TSA plates after incubation for 3 days at $30{ }^{\circ} \mathrm{C}$. The fatty acids were extracted and fatty acid methyl esters were prepared according to the standard protocol of the MIDI/Hewlett Packard Microbial Identification System (Sasser, 1990). The DNA G+C content was determined using the method of Tamaoka \& Komagata (1984), with the modification that DNA was hydrolysed and the resultant nucleotides were analysed by reversed-phase HPLC.

Morphological, cultural, physiological and biochemical characteristics of strain $\mathrm{K}_{107^{\mathrm{T}}}$ are given in the species description or are shown in Table 1. The almost-complete
16S rRNA gene sequences of strain $\mathrm{K} 107^{\mathrm{T}}, M$. dimorpha DSM $7138^{\mathrm{T}}$ and M. ramosa DSM $7292^{\mathrm{T}}$ determined in this study comprised 1441, 1440 and $1440 \mathrm{nt}$, respectively, representing approximately $96 \%$ of the Escherichia coli $16 \mathrm{~S}$ rRNA gene sequence. In the phylogenetic tree constructed using the neighbour-joining algorithm, strain $\mathrm{K}_{107^{\mathrm{T}}}$ joined the cluster comprising the type strains of $M$. dimorpha and $M$. ramosa (Fig. 1). This relationship was maintained in the tree based on the maximum-parsimony algorithm, but not in the tree based on the maximum-likelihood algorithm (Fig. 1). Strain $\mathrm{K}_{107^{\mathrm{T}}}$ exhibited 16S rRNA gene sequence similarity values of 96.3 and $97.1 \%$ with respect to $M$. dimorpha DSM $7138^{\mathrm{T}}$ and M. ramosa DSM $7292^{\mathrm{T}}$, respectively, $96.8 \%$ to Brucella melitensis ATCC $23456^{\mathrm{T}}$, $94.8-96.7 \%$ to the type strains of Ochrobactrum species and $94.7-95.1 \%$ to the type strains of Pseudochrobactrum species. The $\operatorname{rec} A$ gene sequence $(550 \mathrm{nt})$ for strain $\mathrm{K} 107^{\mathrm{T}}$ was determined in this study: it showed the highest level of similarity $(84.5 \%)$ with respect to type strains of Brucella species, the sequences of which are identical. The recA gene sequence of strain $\mathrm{K} 107^{\mathrm{T}}$ had similarity values of $82.0-83.1 \%$ with respect to the type strains of Pseudochrobactrum species, $79.1-80.7 \%$ to the type strains of Ochrobactrum species and $77.6-77.9 \%$ to the type strains of Mycoplana species.

The predominant isoprenoid quinone detected in strain $\mathrm{K} 107^{\mathrm{T}}$ was Q-10 (at a peak area ratio of approximately $95 \%)$; a minor amount of Q-9 (4\%) was present. The major fatty acids (constituting $>10 \%$ of total fatty acids) detected in strain $\mathrm{K}_{107^{\mathrm{T}}}$ were $\mathrm{C}_{18: 1} \omega 7 c(66.2 \%)$ and $\mathrm{C}_{18: 1}$ $2-\mathrm{OH}(10.3 \%)$ (see Supplementary Table S1 in IJSEM Online). This fatty acid profile was similar to those of the two Mycoplana species analysed in this study (Supplementary Table S1). However, the proportions of some fatty acids differed between strain $\mathrm{K}_{107^{\mathrm{T}}}$ and the two Mycoplana species: in particularly, fatty acid $\mathrm{C}_{18: 1} 2-\mathrm{OH}$ was present in significant amounts in strain $\mathrm{K}_{10} 7^{\mathrm{T}}$, but was not detected in either of the two Mycoplana species analysed (Supplementary Table S1). The DNA G+C content of strain $\mathrm{K}_{107^{\mathrm{T}}}$ was $57.0 \mathrm{~mol} \%$.

In the $16 \mathrm{~S}$ rRNA gene sequence analysis, strain $\mathrm{K}_{10} 7^{\mathrm{T}}$ was phylogenetically most closely related to $M$. ramosa.

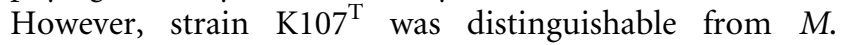
dimorpha and $M$. ramosa on the basis of differences in phenotypic properties, DNA G $+\mathrm{C}$ contents and fatty acid profiles. Strain $\mathrm{K} 107^{\mathrm{T}}$ was also distinguishable from members of the genera Brucella, Ochrobactrum and Pseudochrobactrum on the basis of differences in fatty acid profiles, particularly in the compositions of fatty acids cyclo- $\mathrm{C}_{19: 0} \omega 8 \mathrm{c}$ and $\mathrm{C}_{18: 1}$ 2-OH (although these differences may be the result of differences in cultivation conditions and extraction procedures) (Dees et al., 1980, 1981; Tripathi et al., 2006; Kämpfer et al., 2007) (Table 1). In the phylogenetic analysis based on recA gene sequences, strain $\mathrm{K}_{107^{\mathrm{T}}}$ formed a phylogenetic lineage that is distinct from those of members of the Alphaproteobacteria, including Brucella, Ochrobactrum, Pseudochrobactrum and 
Table 1. Differential phenotypic characteristics of strain $\mathrm{K} 107^{\top}$ and phylogenetically related genera

Taxa: 1, strain $\mathrm{K} 107^{\mathrm{T}}$; 2, Mycoplana [data from Urakami et al. (1990) and this study]; 3, Ochrobactrum (Kämpfer et al., 2007; Teyssier et al., 2007; Tripathi et al., 2006; Zurdo-Piňeiro et al., 2007); 4, Pseudochrobactrum (Kämpfer et al., 2006, 2007); 5, Brucella (Corbel \& Brinley-Morgan, 1984; Dees et al., 1980, 1981). +, Positive; -, negative; v, variable; ND, no data available.

\begin{tabular}{|c|c|c|c|c|c|}
\hline Characteristic & 1 & 2 & 3 & 4 & 5 \\
\hline Growth at $45{ }^{\circ} \mathrm{C}$ & + & - & $\mathrm{V}$ & ND & - \\
\hline Urease & - & + & $\mathrm{V}$ & ND & $\mathrm{ND}$ \\
\hline Nitrate reduction & - & $\mathrm{V}$ & $\mathrm{V}$ & ND & + \\
\hline \multicolumn{6}{|l|}{ Assimilation of: } \\
\hline L-Arabinose & - & + & $\mathrm{v}$ & $\mathrm{v}$ & $\mathrm{V}$ \\
\hline D-Galactose & - & + & $\mathrm{v}$ & $\mathrm{V}$ & $\mathrm{V}$ \\
\hline D-Glucose & + & + & + & V & $\mathrm{V}$ \\
\hline D-Fructose & - & + & $\mathrm{v}$ & V & ND \\
\hline Maltose & - & $\mathrm{V}$ & $\mathrm{v}$ & - & $\mathrm{ND}$ \\
\hline Mannose & + & + & $\mathrm{v}$ & $\mathrm{V}$ & $\mathrm{ND}$ \\
\hline Rhamnose & - & $\mathrm{ND}$ & V & V & $\mathrm{ND}$ \\
\hline Ribose & - & $\mathrm{ND}$ & + or $\mathrm{ND}$ & $\mathrm{V}$ & $\mathrm{V}$ \\
\hline Sucrose & - & $\mathrm{V}$ & V & - & $\mathrm{ND}$ \\
\hline Trehalose & - & - & V & $\mathrm{V}$ & $\mathrm{ND}$ \\
\hline D-Xylose & - & + & + or $\mathrm{ND}$ & $\mathrm{V}$ & $\mathrm{V}$ \\
\hline Glycerol & - & + & ND & $\mathrm{ND}$ & $\mathrm{ND}$ \\
\hline Inositol & + & - & $\mathrm{V}$ & - & ND \\
\hline D-Mannitol & - & + & $\mathrm{v}$ & - & ND \\
\hline D-Sorbitol & - & + & V & - & ND \\
\hline Major fatty acid(s) (>10\% of total) & $\begin{array}{r}\mathrm{C}_{18: 1} \omega 7 c \text { and } \\
\mathrm{C}_{18: 1} 2-\mathrm{OH}\end{array}$ & $\mathrm{C}_{18: 1} \omega 7 c$ & $\begin{array}{c}\mathrm{C}_{18: 1} \omega 7 c \text { and cyclo- } \\
\mathrm{C}_{19: 0} \omega 8 c, \mathrm{C}_{18: 1} 2- \\
\text { OH or } \mathrm{C}_{16: 0}\end{array}$ & $\begin{array}{r}\mathrm{C}_{18: 1} \omega 7 c \text { and cyclo- } \\
\mathrm{C}_{19: 0} \omega 8 c \text { or } \mathrm{C}_{18: 0}\end{array}$ & $\begin{array}{c}\mathrm{C}_{18: 1} \omega 7 c, \mathrm{C}_{16: 0} \text { and } \\
\text { cyclo- } \mathrm{C}_{19: 0} \omega 8 c \text { or } \\
\mathrm{C}_{18: 0}\end{array}$ \\
\hline DNA G $+\mathrm{C}$ content $(\mathrm{mol} \%)$ & 57.0 & $64-65$ & $55-59$ & $50.9^{*}$ & $55-58$ \\
\hline
\end{tabular}

*Data available for Pseudochrobactrum asaccharolyticum only.

Mycoplana (Fig. 2). Accordingly, strain $\mathrm{K} 107^{\mathrm{T}}$ represents a novel genus and species that is distinct from the genera Brucella, Ochrobactrum, Pseudochrobactrum and Mycoplana, for which the name Daeguia caeni gen. nov., sp. nov. is proposed.

\section{Description of Daeguia gen. nov.}

Daeguia (Dae.gu'i.a. N.L. fem. n. Daeguia pertaining to Daegu, the location of the textile dye works from which the type strain of the type species was isolated).

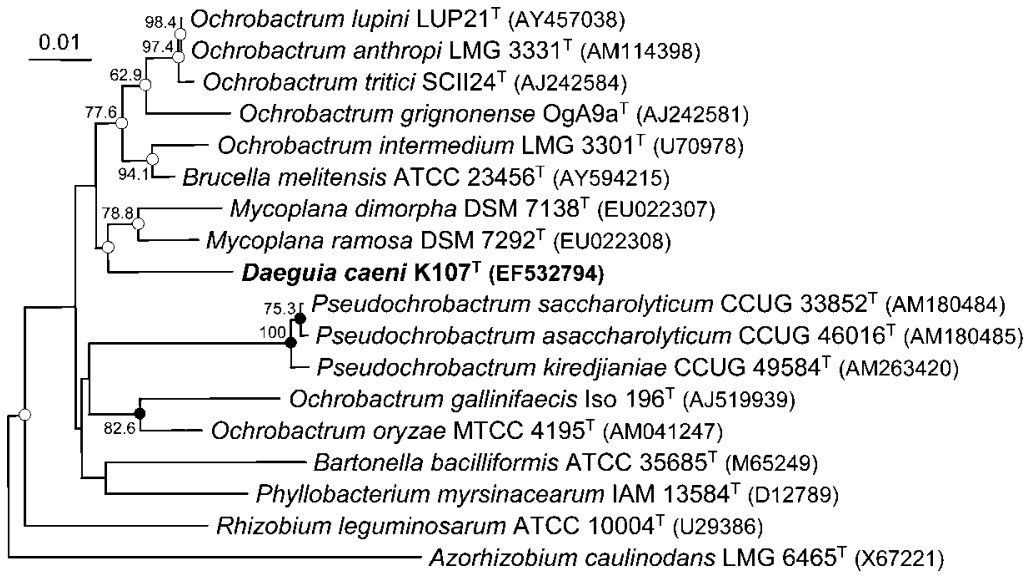

Fig. 1. Neighbour-joining phylogenetic tree, based on 16S rRNA gene sequences (alignment length $1369 \mathrm{bp}$ ), showing the positions of strain $\mathrm{K} 107^{\top}$ and some related taxa. Bootstrap percentages (based on 1000 replications) $>50 \%$ are shown at branching points. Filled circles indicate that the corresponding nodes were also recovered in the trees generated with the maximum-likelihood and maximum-parsimony algorithms. Open circles indicate that the corresponding nodes were also recovered only in the tree generated with the maximum-parsimony algorithm. Azorhizobium caulinodans LMG $6465^{\top}$ was used as an outgroup. Bar, 0.01 substitutions per nucleotide position. 


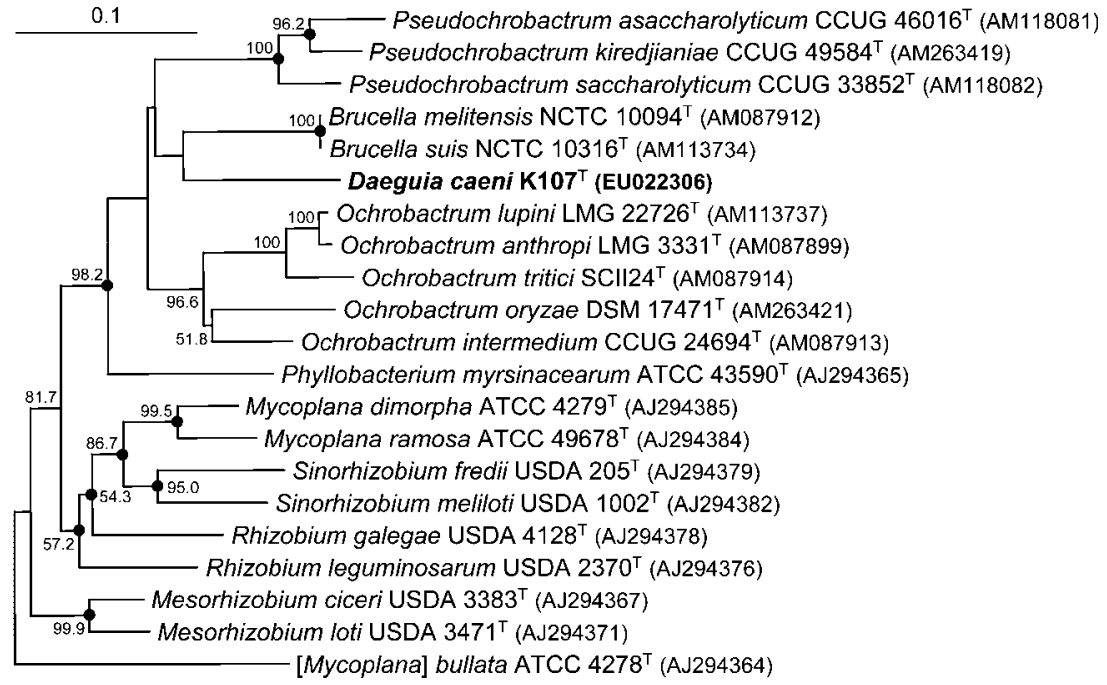

Fig. 2. Neighbour-joining phylogenetic tree, based on partial recA gene sequences (alignment length $504 \mathrm{bp}$ ), showing the positions of strain $\mathrm{K} 107^{\top}$ and some related taxa. Bootstrap percentages (based on 1000 replications) $>50 \%$ are shown at branching points. Filled circles indicate that the corresponding nodes were also recovered in the trees generated with the maximum-likelihood and maximumparsimony algorithms. [Mycoplana] bullata ATCC $4278^{\top}$ was used as an outgroup. Bar, 0.1 substitutions per nucleotide position.
Cells are Gram-negative, non-spore-forming rods. The predominant ubiquinone is $\mathrm{Q}-10$. The major fatty acid is $\mathrm{C}_{18: 1} \omega 7 c$; a significant amount of $\mathrm{C}_{18: 1} 2-\mathrm{OH}$ is present. Exhibits $16 \mathrm{~S}$ rRNA gene sequence similarity values of $94.7-$ $97.1 \%$ with respect to members of the genera Brucella, Mycoplana, Ochrobactrum and Pseudochrobactrum. The recA gene (550 nt) exhibits sequence similarity values of 77.6-84.5\% with respect to the genera Brucella, Mycoplana, Ochrobactrum and Pseudochrobactrum. The DNA G + C content of the type strain of the type species is $57.0 \mathrm{~mol} \%$. The type species is Daeguia caeni.

\section{Description of Daeguia caeni sp. nov.}

Daeguia caeni (cae'ni. L. gen. n. caeni of sludge).

Exhibits the following properties in addition to those given in the genus description. Cells are $0.4-0.6 \times 0.7-2.0 \mu \mathrm{m}$ in size. Colonies on TSA are circular, convex, smooth, glistening, greyish yellow in colour and $1.0-1.5 \mathrm{~mm}$ in diameter after 2 days incubation at $37^{\circ} \mathrm{C}$. The optimal temperature for growth is $30-37^{\circ} \mathrm{C}$. Growth occurs at 15 and $55{ }^{\circ} \mathrm{C}$, but not at 10 or $56{ }^{\circ} \mathrm{C}$. The optimal pH for growth is 7.0-8.0; growth occurs at $\mathrm{pH} 5.0$ and 9.0, but not at $\mathrm{pH} 4.5$ or 9.5. Growth occurs in the presence of $0-4 \%$ $(\mathrm{w} / \mathrm{v}) \mathrm{NaCl}$; optimal growth occurs in the presence of 0.5 $1.0 \%(\mathrm{w} / \mathrm{v}) \mathrm{NaCl}$. No anaerobic growth occurs on TSA or on TSA supplemented with nitrate. Hypoxanthine is hydrolysed, but aesculin, casein, gelatin, starch, tyrosine, xanthine, urea and Tweens 20, 40,60 and 80 are not. Arginine dihydrolase, lysine decarboxylase, ornithine decarboxylase and tryptophan deaminase are absent. $\mathrm{H}_{2} \mathrm{~S}$ and indole are not produced. Adonitol, $\mathrm{N}$-acetylglucosamine and phenylacetate are assimilated and adipate is weakly assimilated, but erythritol, D-arabinose, L-xylose, methyl $\beta$-D-xyloside, sorbose, dulcitol, methyl $\alpha$-D-mannoside, methyl $\alpha$-D-glucoside, amygdalin, arbutin, aesculin, salicin, cellobiose, lactose, melibiose, inulin, melezitose, raffinose, starch, glycogen, xylitol, gentiobiose, turanose,
D-lyxose, D-tagatose, D-fucose, L-fucose, D-arabitol, Larabitol, gluconate, 2-ketogluconate, 5-ketogluconate, caprate, citrate and malate are not assimilated. Alkaline phosphatase, esterase (C4), esterase lipase (C8), leucine arylamidase, acid phosphatase and naphthol-AS-BI-phosphohydrolase are present, but lipase (C14), valine arylamidase, cystine arylamidase, trypsin, $\alpha$-chymotrypsin, $\alpha$-galactosidase, $\beta$-galactosidase, $\beta$-glucuronidase, $\alpha$-glucosidase, $\beta$-glucosidase, $N$-acetyl- $\beta$-glucosaminidase, $\alpha$-mannosidase and $\alpha$-fucosidase are absent. Susceptible to carbenicillin, cephalothin, chloramphenicol, gentamicin, kanamycin, neomycin, novobiocin, streptomycin and tetracycline, but not to ampicillin, lincomycin, oleandomycin, penicillin $G$ or polymyxin B. Other phenotypic characteristics are given in Table 1.

The type strain, $\mathrm{K}_{107^{\mathrm{T}}}\left(=\right.$ KCTC $12981^{\mathrm{T}}=$ CCUG $\left.54520^{\mathrm{T}}\right)$, was isolated from sludge from a textile dye works in Daegu, Korea.

\section{Acknowledgements}

This work was supported by the 21C Frontier Program of Microbial Genomics and Applications (grant MG05-0401-2-0) from the Ministry of Science and Technology (MOST) of the Republic of Korea.

\section{References}

Corbel, M. J. \& Brinley-Morgan, W. J. (1984). Genus Brucella Meyer and Shaw 1920. In Bergey's Manual of Systematic Bacteriology, vol. 1, pp. 377-388. Edited by N. R. Krieg \& J. G. Holt. Baltimore: Williams \& Wilkins.

Cowan, S. T. \& Steel, K. J. (1965). Manual for the Identification of Medical Bacteria. London: Cambridge University Press.

Dees, S., Thanabalasundrum, S., Moss, C. W., Hollis, D. G. \& Weaver, R. E. (1980). Cellular fatty acid composition of group IVe, a nonsaccharolytic organism from clinical sources. J Clin Microbiol 11, 664-668. 
Dees, S. B., Hollis, D. G., Weaver, R. E. \& Moss, C. W. (1981). Cellular fatty acids of Brucella canis and Brucella suis. J Clin Microbiol 14, 111-112.

Gaunt, M. W., Turner, S. L., Rigottier-Gois, L., Lloyd-Macgilp, S. A. \& Young, J. P. W. (2001). Phylogenies of atpD and recA support the small subunit rRNA-based classification of rhizobia. Int J Syst Evol Microbiol 51, 2037-2048.

Kämpfer, P., Rosselló-Mora, R., Scholz, H. C., Welinder-Olsson, C., Falsen, E. \& Busse, H.-J. (2006). Description of Pseudochrobactrum gen. nov., with the two species Pseudochrobactrum asaccharolyticum sp. nov. and Pseudochrobactrum saccharolyticum sp. nov. Int J Syst Evol Microbiol 56, 1823-1829.

Kämpfer, P., Scholz, H., Huber, B., Thummes, K., Busse, H.-J., Maas, E. W. \& Falsen, E. (2007). Description of Pseudochrobactrum kiredjianiae sp. nov. Int J Syst Evol Microbiol 57, 755-760.

Komagata, K. \& Suzuki, K. (1987). Lipid and cell-wall analysis in bacterial systematics. Methods Microbiol 19, 161-207.

Lanyi, B. (1987). Classical and rapid identification methods for medically important bacteria. Methods Microbiol 19, 1-67.

Sasser, M. (1990). Identification of bacteria by gas chromatography of cellular fatty acids, MIDI Technical Note 101. Newark, DE: MIDI Inc.

Tamaoka, J. \& Komagata, K. (1984). Determination of DNA base composition by reversed-phase high-performance liquid chromatography. FEMS Microbiol Lett 25, 125-128.

Teyssier, C., Marchandin, H., Jean-Pierre, H., Masnou, A., Dusart, G. \& Jumas-Bilak, E. (2007). Ochrobactrum pseudintermedium sp. nov., a novel member of the family Brucellaceae, isolated from human clinical samples. Int J Syst Evol Microbiol 57, 1007-1013.

Tripathi, A. K., Verma, S. C., Chowdhury, S. P., Lebuhn, M., Gattinger, A. \& Schloter, M. (2006). Ochrobactrum oryzae sp. nov., an endophytic bacterial species isolated from deep-water rice in India. Int J Syst Evol Microbiol 56, 1677-1680.
Urakami, T., Oyanagi, H., Araki, H., Suzuki, K. \& Komagata, K. (1990). Recharacterization and emended description of the genus Mycoplana and description of two new species, Mycoplana ramosa and Mycoplana segnis. Int J Syst Bacteriol 40, 434-442.

Yoon, J.-H., Kim, H., Kim, S.-B., Kim, H.-J., Kim, W. Y., Lee, S. T., Goodfellow, M. \& Park, Y.-H. (1996). Identification of Saccharomonospora strains by the use of genomic DNA fragments and rRNA gene probes. Int J Syst Bacteriol 46, 502-505.

Yoon, J.-H., Lee, S. T. \& Park, Y.-H. (1998). Inter- and intraspecific phylogenetic analysis of the genus Nocardioides and related taxa based on 16S rRNA gene sequences. Int J Syst Bacteriol 48, 187-194.

Yoon, J.-H., Kang, K. H. \& Park, Y.-H. (2003). Psychrobacter jeotgali sp. nov., isolated from jeotgal, a traditional Korean fermented seafood. Int J Syst Evol Microbiol 53, 449-454.

Yoon, J.-H., Kang, S.-J., Kim, W. \& Oh, T.-K. (2007a). Pigmentiphaga daeguensis sp. nov., isolated from wastewater of a dye works, and emended description of the genus Pigmentiphaga. Int J Syst Evol Microbiol 57, 1188-1191.

Yoon, J.-H., Kang, S.-J., Park, S. \& Oh, T.-K. (2007b). Caenispirillum bisanense gen. nov., sp. nov., isolated from sludge of a dye works. Int J Syst Evol Microbiol 57, 1217-1221.

Yoon, J.-H., Kang, S.-J. \& Oh, T.-K. (2007c). Chryseobacterium daeguense sp. nov., isolated from wastewater of a textile dye works. Int J Syst Evol Microbiol 57, 1355-1359.

Yoon, J.-H., Park, S. E., Kang, S.-J. \& Oh, T.-K. (2007d). Rheinheimera aquimaris sp. nov., isolated from seawater of the East Sea in Korea. Int J Syst Evol Microbiol 57, 1386-1390.

Zurdo-Piňeiro, J. L., Rivas, R., Trujillo, M. E., Vizcaíno, N., Carrasco, J. A., Chamber, M., Palomares, A., Mateos, P. F., Martínez-Molina, E. \& Velázquez, E. (2007). Ochrobactrum cytisi sp. nov., isolated from nodules of Cytisus scoparius in Spain. Int J Syst Evol Microbiol 57, 784-788. 